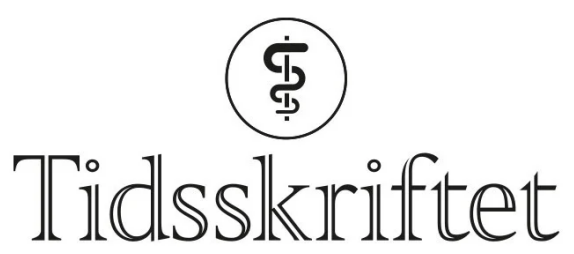

DEN NORSKE LEGEFORENING

\title{
Gunnar Mowé
}

MINNEORD

\author{
SVERRE LANGÅRD
}

FINN LEVY

\section{AXEL WANNAG}

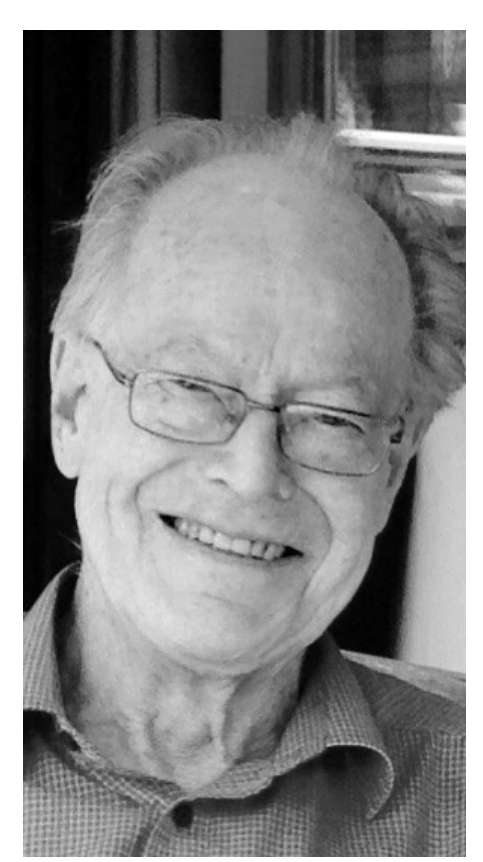

Gunnar Mowé ble født i Oslo den 27.3.1929 og gikk ut av tiden 4.7.2021 etter en tids sykeleie. Han var cand.med. fra Universitetet i Oslo i 1954 og ble godkjent spesialist i indremedisin i 1963 og yrkesmedisin 1977 - som den første i Norge.

Vi har kjent ham som en hedersmann i det arbeidsmedisinske fagfeltet i snart 50 år og møtte ham da han var overlege ved Yrkeshygienisk institutt (YHI) 1974-88. Gunnar hadde da allerede hatt tjeneste i indremedisin ved Ullevål, Aker og Sarpsborg sykehus (1958-65) og som bedriftslege ved Borregaard (1965-73). Der avdekket han som en av de første i verden sammenheng mellom eksponering for hydrokarboner og risiko for alvorlige hjertelidelser. Dette funnet gjorde ham kjent i det arbeidsmedisinske fagmiljøet verden over. 
I Norge er det hans studier om sammenheng mellom asbest og sykdommer som har betydd mest. Tidlig i 1961 tilskrev han Arbeidstilsynet og etterlyste deres viten om asbestose og sammenhengen mellom asbest og lungekreft, men fikk kun ullent svar. Han skrev artikler i Nordisk Medisin om asbestose i 1962 og om asbest og lungekreft i 1970. Da han kom til YHI, samarbeidet han med Isolatørenes fagforening og utførte betydningsfulle arbeider med påvisning av sammenheng mellom arbeid med asbest og høy risiko for lungekreft. Han fortalte beskjedent at han ikke publiserte arbeidet internasjonalt, fordi dr. Selikoff i New York allerede hadde påvist sammenhengen.

Gunnars studie blant isolatører ledet til et glimrende doktorarbeid i 1986 om asbest og lungekreft/mesoteliom, der han også viste sitt sosiale sinnelag ved å skrive en egen artikkel om hvordan det gikk med asbestofrene. Han var pådriver for å få Rikstrygdeverket til å akseptere sammenhengen mellom asbest og mage- og tarmkreft. Etter en tid som overlege i Arbeidstilsynet fullførte han fra 1992 sin løpebane som dommer i Trygderetten.

Han var grundig og ga seg aldri før han kom til bunns i pasientsakene, og søkte alltid sanne svar om sammenhenger mellom eksponering og sykdom. Han har betydd mye for norsk yrkesmedisin og mange kollegaer, og han var en éner i faget i Norge - med et omfattende internasjonalt nettverk.

Gunnar var stolt av sin malaysiske bestefar som kom til Norge som seilskutekipper, og har i de seineste tiårene vært i hyppig kontakt med sine malaysiske slektninger. Skutene hans bestefar seilte, viste han med stolthet fram som malerier hjemme i stua.

Nå er det imidlertid hans barn, barnebarn og oldebarn som tankene våre går til.

Publisert: 27. september 2021. Tidsskr Nor Legeforen. DOI: 10.4045/tidsskr.21.0572

(C) Tidsskrift for Den norske legeforening 2023. Lastet ned fra tidsskriftet.no 26. april 2023. 